\title{
Application of Stabilization/Solidification (S/S) Method for Cadmium Pollution in Surface Sediments of the Dongjiaogou River in Kaifeng, China
}

\author{
Shuya Guo ${ }^{1, *}$, Ling Wang ${ }^{2}$, Hongxia Wang ${ }^{3}$, Bin Yang ${ }^{4}$ and Xijian $\mathrm{Su}^{5}$ \\ ${ }^{1}$ Kaifen Municipal Engineering Design \& Research Co., Ltd., Kaifeng 475000, China; \\ ${ }^{2}$ Kaifeng Urban Comprehensive Administrative Law Enforcement Bureau, Kaifeng 475000, China; \\ ${ }^{3}$ Kaifen Municipal Engineering Design \& Research Co., Ltd., Kaifeng 475000, China; \\ ${ }^{4}$ Kaifen Municipal Engineering Design \& Research Co., Ltd., Kaifeng 475000, China; \\ ${ }^{5}$ Kaifeng Urban Comprehensive Administrative Law Enforcement Bureau, Kaifeng 475000, China;
}

\begin{abstract}
Cd contamination of sediments poses a serious threat to the global environment human health. A detail and comprehensive investigation of cadmium (Cd) pollution in the surface sediments of Dongjiaogou River was carried out. Concentration analysis of $\mathrm{Cd}$ in various depth and locations was conducted based on 82 samples collected from the river surface sediments where the sediments is up to 353 $\mathrm{mg} / \mathrm{kg}$. Subsequently, stabilization/solidification (S/S) method, an effective method of improving the engineering properties of sediments and encapsulating contaminants, was applied in these sediments. According to the results, the Cd pollutant was treated effectively by $\mathrm{S} / \mathrm{S}$ method, which verifies the feasibility to mitigate the hazards caused by $\mathrm{Cd}$ in those sediments from the river. Furthermore, the S/S sediments are favorable as filling material in the road for both recycling and construction.
\end{abstract}

\section{Introduction}

Cadmium $(\mathrm{Cd})$ is a highly toxic environmental pollutant with slow rate of metabolism [1], which enters the sediment through human activities [2]. Cd pollution of waterbodies is an increasing issue due to the fast development of industry, agriculture and other human activities $[3,4]$. As time goes on, the Cd pollution in the water gradually precipitates into the sediments, which serve as a sink for Cd. Previous literature pointed out that $\mathrm{Cd}$ contamination of sediment is increasing dramatically, posing a serious threat to the global aquatic system [5]. Moreover, it also poses adverse impacts of kidneys and the skeleton on human health, even at low exposure level [6].

In China, heavy metal contamination of riverine sediments did not attract much attention from researchers or governments prior to the year 2000 , i.e., relatively few studies were carried out before this time $[7,8]$. Industrial and mining activities always discharge heavy metals into the rivers, especially in the industrial area. Since the 1980 s, plenty of industrial enterprises have moved to suburban areas from mega cities due to the nationwide adjustment of urban layout in China [9-11]. The soil contaminations, especially $\mathrm{Cd}$ contamination at these places, is of increasing concern because of the potential threat to the public health and detrimental effects on the ecosystems [12-14]. Dumping into seas or storing in other locations are the typical disposal strategies for these sediments [15], which result in land occupation and serious ecological environmental degradation [16]. Therefore, stabilization/solidification $(\mathrm{S} / \mathrm{S})$ technique is widely used for treating sediments. Thereinto, cement is the most popular binder used in previous literature and engineering practice [9,17-20]. After improving the sediments, recycling as construction materials is now becoming increasingly preferable alternatives to control these wastes [21, 22].

Since the 1980s, a few enterprises have been built around Dongjiaogou River. Including but not limited to Kaifeng Zinc Smelting Plant, Jinkai Chemical Fertilizer Plant, Kailiu Instrument plant, Kaifeng Qingshang chemical fertilizer Co., Ltd. A large amount of wastewater generated from those enterprises was directly discharged into this river. As a consequence, the suspended solids in the wastewater were slowly deposited in the river, which led to the sediment pollution. Since the waste residue generated from those enterprises was undisposed at all, there were high level of heavy metal pollutants in those sediments. This study takes Dongjiaogou River as the target area and investigate the sediments $\mathrm{Cd}$ pollutants via concentration analysis. Furthermore, the feasibility to eliminate the polluted sediments based on $\mathrm{S} / \mathrm{S}$ method is evaluated and discussed.

$\overline{\text { *Corresponding author: cc15@albion.edu }}$ 


\section{Area Description}

Dongjiaogou River is about $9.5 \mathrm{~km}$ in length, located in the eastside of Kaifeng, China (as shown in Figure 1a). The surrounding buildings are relatively evacuated and farmland, industrial factories as well as some sewage outlets are spread around. The pollution sources in the river mainly came from rainwater, domestic sewage and factory wastewater along the river. The water quality of the river was poor and had a negative impact on the living environment.

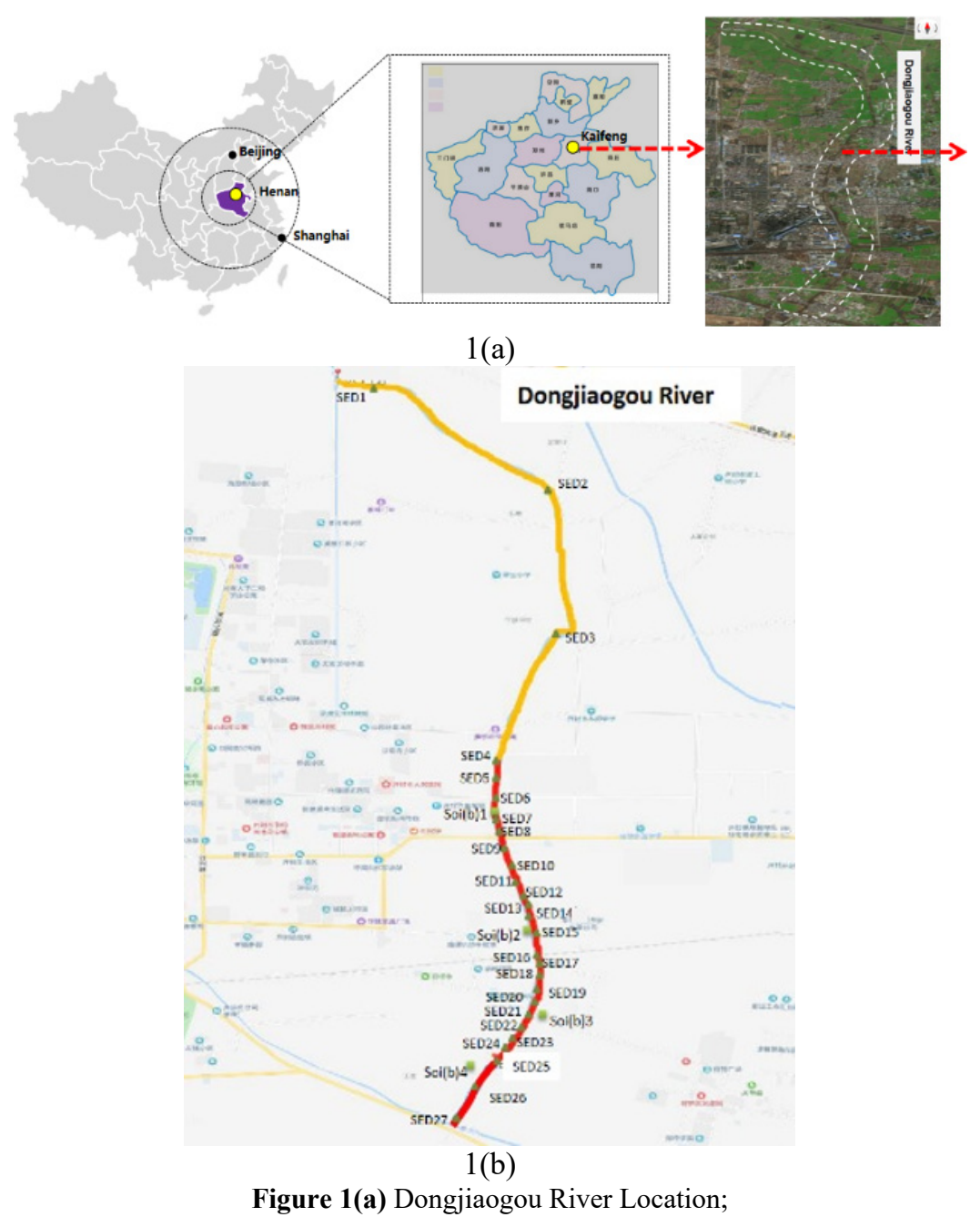

1(b) 27 Sample Sections along Dongjiaogou River. The maps are collected from Baidu maps

\section{Samples and Method}

The 82 sediments samples used in this study were dredged by different depth from 27 sample sections (see from Figure. 1b) along Dongjiaogou River. After dehydration and grinding to powder, the $\mathrm{Cd}$ content experiment was carried out by oil quality-determination of lead cadmiumgraphite furnace atomic absorption spectrophotometry method [23].

According to previous literature [24,25], $\mathrm{S} / \mathrm{S}$ is considered as an effective method (using cement and other binders) for both improving the engineering properties of sediments as well as encapsulating contaminants. Cement treatment is combined with the development of physical-chemical processes [26]. In detail, hydration reactions produce calcium hydroxide $(\mathrm{Ca}(\mathrm{OH}) 2)$, calcium silicate hydrates $(\mathrm{CSH})$, calcium aluminate hydrates $(\mathrm{CAH})$ and ettringite $(\mathrm{Aft})$, which fill the soil pores and cement soil particles [27]. Cation exchange causes the flocculation and agglomeration of soil particles with the consumption of $\mathrm{Ca} 2+$, which fills the pores and further strengthens the aggregate structure [28]. As these hydrates crystallize and harden over time, the engineering behaviors of stabilized soil will be improved (e.g., strength, permeability and swelling) and contaminants will be immobilized [29-32].

\section{Results}

Table 1 lists the results of the $\mathrm{Cd}$ for all the samples selected. From location Sed 1 to location Sed 4, the Cd contamination is undetected. However, starting from location Sed 5, the Cd contamination exists in different depths, which varies from $0.3 \mathrm{mg} / \mathrm{kg}$ to $353 \mathrm{mg} / \mathrm{kg}$. According to Soil Environmental Quality - Risk Control Standard for Soil Contamination of Development Land [33], the results indicates that majority dredged sediment 
$\mathrm{Cd}$ content exceed the prescribed limits of the soil contamination of $\mathrm{Cd}$ (illustrated in Figure 2).

Figure 3 presents the statistic of $\mathrm{Cd}$ content grouped by different depth, where one sees the Cd contamination on the shallow depth is heavier than the deeper cases. After the S/S method applying to treat the river sediments, another 40 samples were chosen along the river for every
$100 \sim 300$ meters. The experiments was conducted by Solid Waste-Extraction procedure for leaching toxicityacetic acid buffer solution method (described in Ref. [34]). According to the experiments, $\mathrm{Cd}$ leaching content results less than $0.01 \mathrm{mg} / \mathrm{L}$, which demonstrates that the $\mathrm{S} / \mathrm{S}$ method work effectively for Cd pollution.

Table 1. Experiment results of sediment samples

\begin{tabular}{|c|c|c|c|c|c|c|c|c|c|c|c|}
\hline \multicolumn{3}{|c|}{ Location } & \multirow{2}{*}{$\begin{array}{c}\text { Results } \\
\begin{array}{c}\mathrm{Cd} \\
\mathrm{mg} / \mathrm{kg}\end{array}\end{array}$} & \multicolumn{3}{|c|}{ Location } & \multirow{2}{*}{$\begin{array}{c}\text { Results } \\
\mathrm{Cd} \\
\mathrm{mg} / \mathrm{kg}\end{array}$} & \multicolumn{3}{|c|}{ Location } & \multirow{2}{*}{$\begin{array}{c}\text { Results } \\
\begin{array}{c}\mathrm{Cd} \\
\mathrm{mg} / \mathrm{kg}\end{array}\end{array}$} \\
\hline $\begin{array}{l}\text { Section } \\
\text { Name }\end{array}$ & Sample Name & $\begin{array}{c}\text { Sample } \\
\text { Depth(m) }\end{array}$ & & $\begin{array}{l}\text { Section } \\
\text { Name }\end{array}$ & Sample Name & $\begin{array}{c}\text { Sample } \\
\text { Depth(m) }\end{array}$ & & $\begin{array}{c}\text { Section } \\
\text { Name }\end{array}$ & Sample Name & $\begin{array}{c}\text { Sample } \\
\text { Depth(m) }\end{array}$ & \\
\hline \multirow{5}{*}{ SED1 } & SED1-1 & 0.2 & $<0.01$ & \multirow{5}{*}{ SED12 } & SED12-1 & 0.2 & 160 & \multirow{3}{*}{ SED21 } & SED21-1 & 1.0 & 66.4 \\
\hline & $\begin{array}{c}\text { SED1-1 } \\
\text { Parallelism }\end{array}$ & 0.2 & $<0.01$ & & \multirow[t]{2}{*}{ SED12-2 } & \multirow[t]{2}{*}{0.5} & \multirow[t]{2}{*}{82.8} & & \multirow[t]{2}{*}{ SED21-2 } & \multirow[t]{2}{*}{2.0} & \multirow[t]{2}{*}{29.6} \\
\hline & SED1-2 & 0.5 & $<0.01$ & & & & & & & & \\
\hline & SED1-3 & 1.0 & $<0.01$ & & \multirow[b]{2}{*}{ SED12-3 } & \multirow[b]{2}{*}{1.0} & \multirow[b]{2}{*}{54.9} & \multirow{3}{*}{ SED22 } & \multirow[b]{2}{*}{ SED22-1 } & \multirow[b]{2}{*}{1.0} & \multirow[b]{2}{*}{88.6} \\
\hline & $\begin{array}{c}\text { SED1-3 } \\
\text { Parallelism }\end{array}$ & 1.0 & $<0.01$ & & & & & & & & \\
\hline SED2 & SED2-1 & 0.5 & $<0.01$ & \multirow{3}{*}{ SED13 } & SED13-1 & 0.5 & 87.3 & & SED22-2 & 2.0 & 50.5 \\
\hline SED3 & SED3-1 & 0.5 & $<0.01$ & & SED13-2 & 1.0 & 63.6 & \multirow{3}{*}{ SED23 } & SED23-1 & 0.5 & 50.6 \\
\hline SED4 & SED4-1 & 0.5 & $<0.01$ & & SED13-3 & 1.5 & 52.9 & & SED23-2 & 1.5 & 12.0 \\
\hline \multirow{4}{*}{ SED5 } & SED5-1 & 0.5 & $<0.01$ & & SED14-1 & 0.5 & 89.2 & & SED23-3 & 2.0 & 12.5 \\
\hline & SED5-2 & 1.0 & 56.5 & SED14 & SED14-2 & 1.0 & $\begin{array}{l}55.8 \\
\end{array}$ & & SED24-1 & 0.5 & 86.1 \\
\hline & SED5-3 & 1.5 & 12.6 & & & & & & & & \\
\hline & $\begin{array}{c}\text { SED5-3 } \\
\text { Parallelism }\end{array}$ & 1.5 & 12.8 & SED15 & SED15-1 & 0.5 & 353 & SED24 & SED24-2 & 1.0 & 15.4 \\
\hline & SED6-1 & 0.5 & 90.9 & & SED15-2 & 1.0 & 82.2 & & SED24-3 & 1.5 & 12.4 \\
\hline SED6 & SED6-2 & 1.0 & 56.7 & & SED15-3 & 1.5 & 4.52 & & SED25-1 & 0.5 & 13.0 \\
\hline & SED7-1 & 0.5 & 163 & & SED16-1 & 0.5 & 92.0 & SED25 & SED25-2 & 1.0 & 13.3 \\
\hline & SED7-2 & 1.0 & 57.8 & & SED16-2 & 1.0 & 66.0 & & SED25-3 & 1.5 & 9.92 \\
\hline SED7 & & & & SED16 & SED16-3 & 1.5 & 10.0 & & & & \\
\hline & SED7-3 & 1.5 & 58.9 & & $\begin{array}{c}\text { SED16-3 } \\
\text { Parallelism } \\
\end{array}$ & 1.5 & 10.1 & SED26 & SED26-1 & 0.5 & 73.9 \\
\hline & SED8-1 & 0.5 & 92.3 & & SED17-1 & 0.5 & 124 & & SED26-2 & 1.0 & 55.7 \\
\hline SED8 & & & & & & & & & SED27-1 & 0.5 & 1.30 \\
\hline SED8 & SED8-2 & 1.0 & 56.1 & SED17 & SED17-2 & 1.0 & 74.5 & SED27 & $\begin{array}{c}\text { SED27-1 } \\
\text { Parallelism } \\
\end{array}$ & 0.5 & 1.28 \\
\hline & SED9-1 & 0.2 & 255 & & SED17-3 & 1.5 & 22.5 & & SED27-2 & 1.0 & 1.28 \\
\hline & SED9-2 & 0.5 & 161 & & SED18-1 & 0.5 & 94.1 & & SED27-3 & 1.5 & 0.30 \\
\hline SED9 & & & & & & & & & Soil(b)1 & 0.2 & 1.26 \\
\hline & SED9-3 & 1.0 & 63 & SED18 & SED18-2 & 1.0 & 49.8 & CG1 & $\begin{array}{c}\text { Soil(b)1 } \\
\text { Parallelism }\end{array}$ & 0.2 & 1.33 \\
\hline & SED10-1 & 0.5 & 92.7 & & SED18-3 & 1.5 & 33.6 & CG2 & Soil(b)2 & 0.2 & 0.93 \\
\hline & SED10-2 & 1.0 & 60.3 & & SED19-1 & 0.5 & 49.9 & & Soil(b)3 & 0.2 & 1.22 \\
\hline SED10 & & & & & SED19-2 & 1.0 & 10.3 & CG3 & $\begin{array}{c}\text { Soil(b)3 } \\
\text { Parallelism } \\
\end{array}$ & 0.2 & 1.13 \\
\hline & SEDI0-3 & 1.5 & 44.1 & SED19 & $\begin{array}{c}\text { SED19-2 } \\
\text { Parallelism }\end{array}$ & 1.0 & 10.5 & CG4 & Soil(b)4 & 0.2 & 1.35 \\
\hline & SED11-1 & 0.2 & 91 & & SED19-3 & 1.5 & 12.6 & & & & \\
\hline & SED11-2 & 0.5 & 50.7 & & SED20-1 & 0.5 & 86.4 & & & & \\
\hline SEDII & SED11-3 & 1.5 & 45.7 & SED20 & SED20-2 & 1.5 & 63.6 & & & & \\
\hline & SED11-4 & 2.0 & 35.7 & & SED20-3 & 2.0 & 29.3 & & & & \\
\hline
\end{tabular}

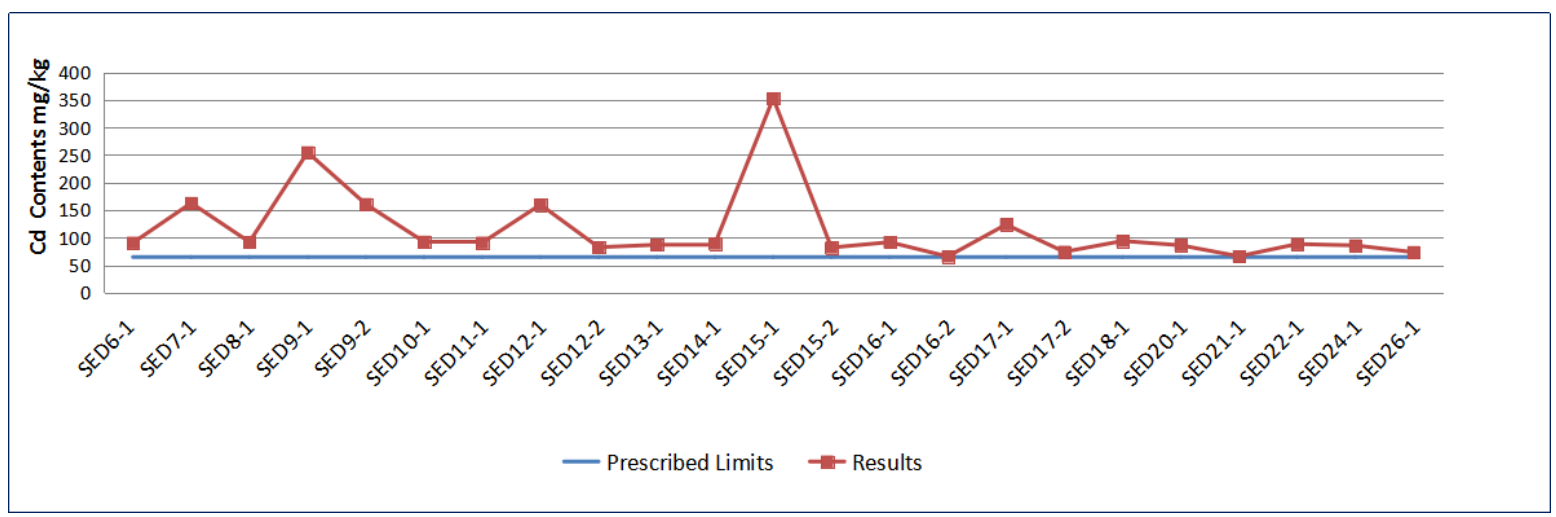

Figure 2. Cd content compared with prescribed limits given by Ref. [33] 


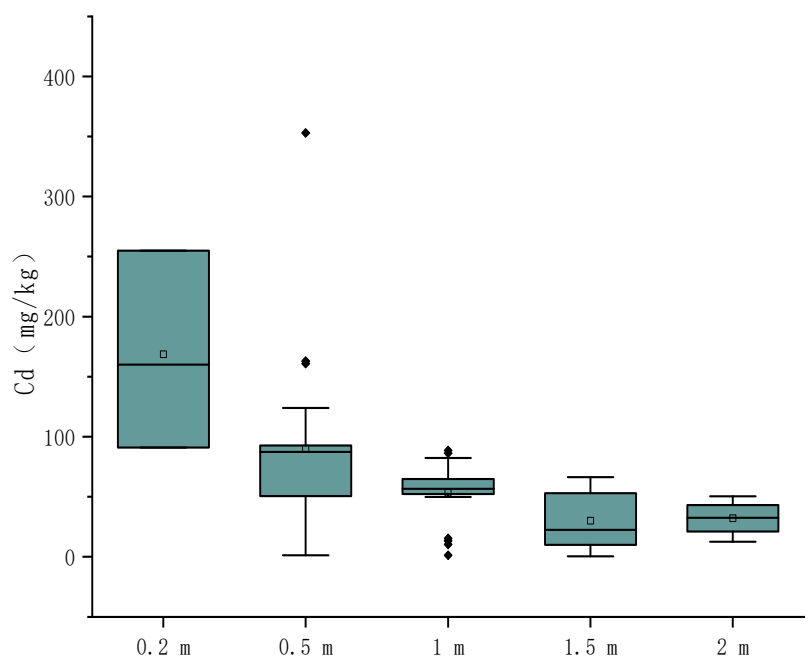

Figure 3. The statistic boxplot for content of Cd grouped by sampling depth.

\section{Discussion}

Sediments contain many pollutants besides $\mathrm{Cd}$, e.g., nitrogen, phosphorus pollutants, and organic pollutants [35-37]. As a matter fact, $\mathrm{S} / \mathrm{S}$ applied here not only promotes the strength and stiffness of sediments, but also reduces the contaminant of $\mathrm{Cd}$. The $\mathrm{S} / \mathrm{S}$ method exhibits the characteristics of low permeability, high strength, high stiffness and low cost. Furthermore, the S/S sediments could be widely utilized as materials on the project, e.g., road layers, river embankments, and foundation treatment (depicted in Figure 4) [35,36,38-42]. To recycle the S/S sediments, a viable path is proposed to reuse them as the road foundation next to the Dongjiaogou River. By this means, it saves the costs of the project itself while also ensure the safety of the treatments.

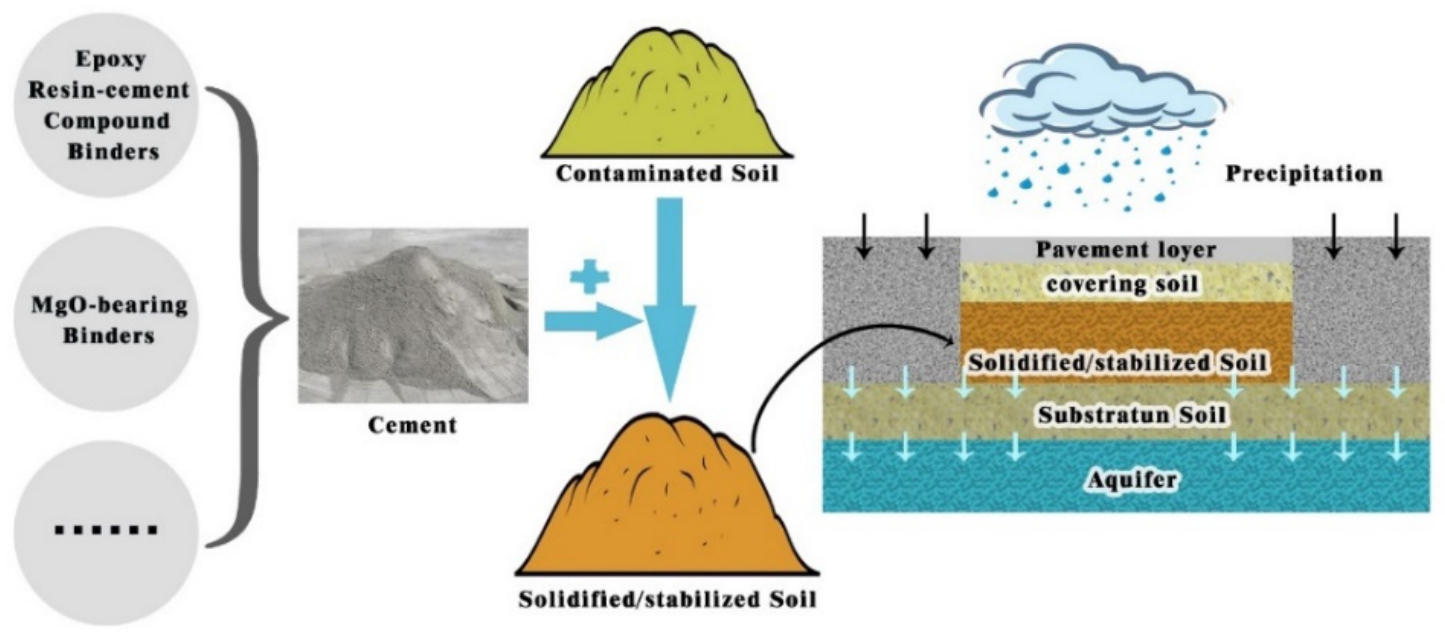

Figure 4. Recycling soil as road foundation

Although the $\mathrm{S} / \mathrm{S}$ is a widely used method for sediment treatment, the accurate proportion of the binder selection should be addressed. The solidification agents for $\mathrm{S} / \mathrm{S}$ sediments were cement initially. Subsequently, based on the physical and chemical properties of the sediments, other binders are added. For example, lime [43-45], epoxy resin-cement compound binders [46], MgO-bearing binders [47], cement-based mixture, use of alkali activators, expansive components and surfactants [48] are optional choice.

\section{Conclusion}

In summary, Dongjiaogou River was seriously polluted by $\mathrm{Cd}$ from location Sed 5 to Sed 27 according to concentration analysis. Besides, the surface level of sediment was polluted heavier than the inner level. Based on $\mathrm{S} / \mathrm{S}$ method treatment, the $\mathrm{Cd}$ contamination in the sediment of this river was controlled effectively, where all the $\mathrm{Cd}$ leaching content shows less than $0.01 \mathrm{mg} / \mathrm{L}$. Moreover, the $\mathrm{S} / \mathrm{S}$ sediments were composed of sediment 
aggregates, i.e., they can serve as the construction material. These results verify the feasible path to improve the Cd pollution in the river by means of $\mathrm{S} / \mathrm{S}$.

\section{References}

1. Lars, Agenta,2009.Current status of cadmium as an environmental health problem ScienceDirect.Toxicology and Applied Pharmacology.238(3),201-208.

2. Murtaza, G., Javed, W., Hussain, A., Wahid, A., Murtaza, B., Owens, G., 2015. Metaluptake via phosphate fertilizer and city sewage in cereal and legume crops in Pakistan. Environ. Sci. Pollut. Res. 22(12), 9135-9147

3. Gao, Q., Li, Y., Cheng, Q., Yu, M., Hu, B., Wang, Z., Yu, Z., 2016. Analysis and assessment of the nutrients, biochemical indexes and heavy metals in the Three Gorges Reservoir, China, from 2008 to 2013. Water Res. 92, 262-274.

4. Harukumar, P.S., Nasir, U.P., Rahman, M.P.M., 2009. Distribution of heavy metals in the core sediments of a tropical wetland system. Int. J. Environ. Sci. Tech. 6(2) 225-232.

5. Kucuksezgin, F., Uluturhan, E., Batkin, H., 2008. Distribution of heavy metals in water, particulate matter and sediments of Gediz River (Eastern Aegean). Environ. Monit. Access. 141, 213-225

6. UNEP, 2010. Final Review of Scientific Information on Cadmium. UNEP, Geneva.

7. He, M.C., Wang, Z.J., Tang, H.X., 1998. The chemical, toxicological and ecological studies in assessing the heavy metal pollution in Le An River, China. Water Res. 32, 510-518.

8. Zhao, Y., Marriott, S., Rogers, J., Iwugo, K., 1999. A preliminary study of heavy metal distribution on the flood plain of the River Severn, UK by a single flood event. Sci. Total Environ. 244., 219-231.

9. Du, Y.J., Jiang. N.J., Liu, S.Y., Jin, F., Singh, D.N., Puppala, A.J., 2014. Engineering properties and microstructural characteristics of cement stabilized zinc-contaminated kaolin. Can. Geotech. J., 51(3):289-302

10. Yang, Y.L., Reddy, K.R., Du, Y.J., Fan, R.D., 2018. Short-term hydraulic conductivity and consolidation properties of soil-bentonite backfills exposed to CCR-impacted groundwater. J. Geotech. Geoenviron. Eng., 144(6): 04018025.

11. Zhou, Y., Liu, Y., 2018. China's fight against soil pollution. Science, 362(6412): 298.

12. Feng, Y.S., Du. Y.J., Reddy, K.R., Xia, W.Y., 2018. Performance of two novel binders to stabilize field soil with zinc and chloride: Mechanical properties, leachability and mechanisms assessment. Constr. Build. Mater., 189: 1191-1199.

13. Xia, W.Y., Du, Y.J., Li, F.S., Li, C,P., Yan, X.L., Arulrajah, A., Wang F., Song, D.J., 2019. In-situ solidification/stabilization of heavy metals contaminated site soil using a dry jet mixing method and new hydroxyapatite based binder. J. Hazard. Mater., 379: 353-361.

14. Du, Y.J., Wu, J., Bo, Y.L., Jiang, N.J., 2020 Effects of acid rain on physical, mechanical and chemical properties of GGBS-MgO-Solidified/stabilized $\mathrm{Pb}-$ contaminated clayey soil. Acta Geotech., 15: 923-932.

15. Bates, M.E., Fox-Lent, C., Seymour, L., Wender, B.A., Linkov, I., 2015. Life cycle assessment for dredged sediment placement strategies. Sci. Total Environ. 511, 308-318.

16. Howard, I.L., Vahedifard, F., Williams, J.M., Timpson, C., 2018. Geotextile tubes and beneficial reuse of dredged soil: applications near ports and harbours. Proc. Inst. Civ. Eng.-Ground Improv. 171, 244-257

17. Sharma, H.D., Reddy, K.R., 2004. Geoenvironmental envineering: site remediation, waste containment, and emerging waste management technologies, John Wiley\& Sons, New York.

18. Spence, R.D., Shi, C., 2004. Stabilization and Solidification of Hazardous, Radioactive, and Mixed Wastes, CRC Press, Boca Raton.

19. Tian, Q., Nakama, S., Sasaki, K., 2019. Immobilization of cesium in fly ash-silica fume based geopolymers with different $\mathrm{Si} / \mathrm{Al}$ molar ratios. Sci Total Environ., 687: 1127-1137.

20. Zhang W.J., Lin M.F., 2020. Influence of redox potential on leaching behavior of a solidified chromium contaminated soil. Sci. Total Environ., 733: 139410.

21. Kogbara, R.B., 2017. Interrelationships among geotechnical and leaching properties of a cementstabilized contaminated soil. J. Environ. Sci. Heal. Part A 52(2), 149-157

22. Li, W., Ni, P., Yi, Y.m 2019. Comparison of reactive magnesia, quick lime, and ordinary Portland cement for stabilization/solidification of heavy metalcontaminated soils. Sci. Total Environ. 671, 741-753

23. Soil quality-determination of lead cadmium-graphite furnace atomic absorption spectrophotometry GB/T17141-1997

24. Bao, J., Wang, L., Xiao, M., 2016. Changes in speciation and leaching behaviors of heavy metals in dredged sediment solidified/stabilized with various materials. Environ. Sci. Pollut. Res. 23(9), 1-8.

25. Wang, P., Xue, Q., Yang, Z., Li, J., Zhang, T., Huang, Q., 2017. Factors affecting the leaching behaviors of magnesium phosphate cement-stabilized/solidified $\mathrm{Pb}$-contaminated soil, part II: dosage and curing age. Environ. Prog. Sustain. Energy.

26. Senneca, O., Cortese, L., Di Martino, R., Fabbricino, M., Ferraro, A., Race, M., Scopino, A., 2020. Mechanisms affecting the delayed efficiency of cement based stabilization/solidification processes. J. Clean Prod. 261, 
27. Shinsha, H., Kumagai, T., 2018. Material properties of solidified soil grains produced from dredged marine clay. Soils Found. 58(3). 678-688.

28. Sharma, L.K., Sirdesai, N.N., Sharma, K.M., Singh, T.N., 2018. Experimental study to examine the independent roles of lime and cement on the stabilization of a mountain soil: a comparative study. Appl. Clay Sci. 152, 183-195.

29. Gu, K., Chen, B., 2020. Loess stabilization using cement, waste phosphogypsum, fly ash and quicklime for self-compacting rammed earth construction. Constr. Build. Mater. 231.

30. Kumaravelu, P., Azmi, M., Mohd Yusoff, S.A.N., 2020. Study on the characteristic of marine dredged sediment using admixture. Proceedings of AICCE'19, Cham.

31. Wang, D., Zentar, R., Abriak, N.E., Di, S., 2018. Long-term mechanical performance of marine sediments solidified with cement, lime and fly ash. Mar. Geores. Geotechnol. 36(1), 123-130.

32. Yi, Y., Liska, M., Unluer, C., Al-Tabbaa, A., 2013. Carbonating magnesia for soil stabilization. Can. Geotech. J. 50(8), 899-905.

33. Solid waste - Determination of 22 metal elements Inductively coupled plasma optical emission spectrometry, HJ 781-2016, 2016, Ministry of Environmental Protection of the People's Republic of China.

34. Solid waste - Determination of 22 metal elements Inductively coupled plasma optical emission spectrometry, HJ 781-2016, 2016, Ministry of Environme

35. -ntal Protection of the People's Republic of China.

36. J. Park, Y. Son, S. Noh, T. Bong, The suitability evaluation of dredged soil from reservoirs as embankment material, J. Environ. Mange. 183(2016) 443-452.

37. S. Rakshith, D.N. Singh, Utilization of dredged sediments: contemporary issues, J. Waterw. Port, Coast Ocean Eng. 143(2017)1-13.

38. A.T. Hejabi, S.L. Belagali, Survey of trace metal contaminants in sediments of kabini river in the nanjangud industrial area, mysore district, Nat. Environ. Pollut. Techno. 8(2009) 49-52.

39. R.Zentar, D. Wang, N.E. Abriak, M. Benzerzour, W. Chen, Utilization of siliceous-aluminous fly as and cement for solidification of marine sediments, Constr. Build. Mater. 35(2012) 856-863.

40. S. Kamali, F. Bernard, E. Abriak Nor, P. Degrugilliers, Marine dredged sediments as new materials resource for road construction, Waste Manag. 28(2008) 919-928.

41. L. Wang, D.C.W. Tsang, C.S. Poon, Green remediation and recycling of contaminated sediment by waste-incorporated stabilization/solidification, Chemosphere 122(2015) 257-264.
42. S.-Y. Pu, Z.-D.Zhu, W.-L.Song, H.-R. Wang, R.-J. Wei, Deformation properties of silt solidified with a new SEU-2 binder, Constr, Build. Mater. 220(2019) 267-277.

43. L. Swierczek, B.M. Cieslik, P. Konieczka, The potential of raw sewage sludge in construction industry - a review. J. Clean. Prod. 200(2018) 342356.

44. D. Wang, N.E. Abriak, R. Zentar, Strength and deformation properties of Dunkird marine sediments solidified with cement, lime and fly ash, Eng. Geol. 166(2013) 90-99.

45. F.G. Bell, Lime stabilization of clay minerals and soils, Eng. Geol. 42(1996) 223-237.

46. K. Lemaire, D. Deneele, S. Bonnet, M. Legret, Effects of lime and cement treatment on the physicochemical, microstructural and mechanical characteristics of a plastic silt, Eng. Geol. 166(2013) 255-261.

47. C.A. Anagnostopoulos, Strength properties of an epoxy resin and cement-stabilized silty clay soil, Appl. Clay Sci. 114 (2015) 517-529

48. F. Jin, F. Wang, A. Al-tabbaa, Three-year performance of in-situ solidified/stabilized soil using novel MgO-bearing binders, Chemosphere 144(2016) 681-688.

49. S.-Y. Pu, Z.-D. Zhu, W.-L. Song, H.-R. Wang, R/-J. Wei, Deformation properties of silt solidified with a new SEU-2 binder, Constr. Build. Mater. 220(2019) 267-277 